ISSN 1392-3196 / e-ISSN 2335-8947

Zemdirbyste-Agriculture, vol. 107, No. 2 (2020), p. 153-160

DOI 10.13080/z-a.2020.107.020

\title{
Breeding potential of maize landraces evaluated by their testcross performance
}

\author{
Aleksandar POPOVIĆ ${ }^{1}$, Natalija KRAVIĆ ${ }^{1}$, Milosav BABIĆ ${ }^{2}$, Slaven PRODANOVIĆ ${ }^{3}$, \\ Mile SEČANSKI ${ }^{1}$, Vojka BABIĆ ${ }^{1}$ \\ ${ }^{1}$ Maize Research Institute "Zemun Polje" \\ Slobodana Bajića 1, 11185 Belgrade, Serbia \\ E-mail: apopovic@mrizp.rs \\ ${ }^{2}$ Institute of Field and Vegetable Crops \\ Maksima Gorkog 30, 21000 Novi Sad, Serbia \\ ${ }^{3}$ University of Belgrade, Faculty of Agriculture \\ Nemanjina 6, 11080 Belgrade, Serbia
}

\begin{abstract}
Significant amounts of crop diversity, especially in out-crossing species like maize (Zea mays L.) is, are often distributed both between and within related groups of accessions. Thus, a detailed characterization and classification of gene bank accessions should be performed prior to use of the best of them for introgression programs to enlarge the genetic base of the elite germplasm pool. Based on performances per se, 40 landraces were chosen out of the wide pool of Western Balkan landraces, previously clustered into 11 homogenous groups. The objective of this study was to evaluate the heterotic pattern of landraces in testcrossing with three divergent elite testers L217, L73B013 and L255/75-5. According to the results of a two-year trial conducted at four locations, landraces 1267, 1346, 197, 1569, 1509 and 2036 expressed the best general combining abilities (GCA) for grain yield. Landraces $1960,642,2006,1945,1346,1569,1450,1534,1509$ and 1665 performed well in crosses to L217, while landraces $1960,773,1798,1665,632,877$ and 1569 gave the best results in crosses to inbred tester L73B013. In crosses to inbred tester L255/75-5, the highest heterotic effects were expressed by landraces 467, 773, 1346, 1534, 2249 and 288. Particular attention is to be paid to landraces 1346, 1569 and 1509, having simultaneously high GCA and specific combining abilities (SCA). A certain number of landraces expressed heterosis with two inbred testers, indicating existence of a new unrelated heterotic pattern within the local germplasm pool evaluated.
\end{abstract}

Key words: general combining abilities, genetic resources, heterotic pattern, specific combining abilities, yield, Zea mays.

\section{Introduction}

It is estimated that breeders' working collections encompass only $3-5 \%$ of preserved maize variability (Curry, 2017). On the other hand, maize has one of the richest reserves of genetic resources of all major crop species (Ortiz et al., 2010). Generally, richness of genetic resources stored in gene banks is rarely used in plant breeding (Technow et al., 2014). There are numerous objective reasons for this situation, such as: the lack of documentation and the appropriate collection description, the lack of information important for breeding, samples with limited adaptability and seed quantities. Additional obstacle is a large number of gene bank samples that are usually loaded with many unfavourable properties from the aspects of modern cropping practices and breeding. Therefore, activities aimed at characterisation and improvement of gene bank material are an expensive and long-term process, while the final results, in a commercial sense, are uncertain (Gorjanc et al., 2016).
Pre-breeding is the most natural link between genetic resources and commercial breeding. It represents a number of activities for identification of favourable traits and/or genes contained in unselected materials. These programs may represent development of new pools for breeding as well as identification of new heterotic patterns in maize (Nass, Paterniani, 2000; Shimelis, Laing, 2012). However, a few such programmes are a limiting factor for more extensive utilisation of landraces from gene bank collections, where many of them were collected before disappearing from practical cultivation in foresight of their value for future generations (Böhm et al., 2015).

The heterosis is a quantitative measure of hybrid superiority over its parental components and it has been widely used in maize breeding programs (Hallauer et al., 2010). In order to efficiently exploit the effect of heterosis, the concept of heterotic groups and patterns was suggested. Heterotic pattern implies subdivision of the

Please use the following format when citing the article:

Popović A., Kravić N., Babić M., Prodanović S., Sečanski M., Babić V. 2020. Breeding potential of maize landraces evaluated by their testcross performance. Zemdirbyste-Agriculture, 107 (2): 153-160. DOI 10.13080/z-a.2020.107.020 
existing germplasm to at least two genetically divergent populations and their interpopulation improvement (Vančetović et al., 2015 a). Enhancement of maize genetic resources and population improvement are vital to protect the gains in maize yield made to date, continuing to drive increases in genetic yield potential (Ortiz et al., 2010). However, molecular analyses revealed that only a small portion of the rich genetic variation present in European landraces has been captured in the current elite flint germplasm (Hölker et al., 2019).

The evaluation of five distinct Central European open pollinated maize cultivars, 85 hybrids and their parental components with a total of 55 SSR markers revealed that genetic variation within and among cultivars decreased significantly during the last five decades (Reif et al., 2005) and is almost certainly limited in comparison to the large genetic diversity available in gene banks (Le Clerc et al., 2005). Numerous unique alleles present in these open pollinated maize cultivars were lost in the elite flint pool, which imposes a necessity to enlarge genetic base in breeding programmes. There is a huge yet unexploited genetic diversity in maize landraces as a product of thousands years of evolution under domestication and hybridization. Considering the genetic variation within the flint landraces, it seems promising to use the best of them for introgression programs to enlarge the genetic base of the elite flint germplasm pool in Central Europe (Böhm et al., 2015). Landraces adapted to local growth conditions could play significant role in this process and, according to Mikić et al. (2017), even the smallest participation of local germplasm can have a great impact on the final result.

Out of 5806 accessions stored and maintained in the gene bank collection at Maize Research Institute "ZemunPolje", 2217 accessions are local landraces (Andjelkovic, Ignjatovic-Micic, 2012). Pre-breeding activities are carried out through the long-term process of characterization and evaluation of gene banks accessions and through the selection of a smaller number of genotypes with favourable properties, in order to introgress them into elite breeding material (Vančetović et al., $2015 \mathrm{~b}$ ).

Part of Maize Research Institute Gene Bank pre-breeding activities is focused on 310 local landraces, collected from the Western Balkan region. After classification of these landraces into eleven homogenous groups (Babić et al., 2015), the objective of this study was (i) to select a smaller number (approximately 10 $15 \%$ of representative maize (Zea mays L.) landraces of each homogenous group) based on characterisation and evaluation of agronomic traits of interest for breeding in order to retain as much genetic variability as possible, and (ii) to define heterotic patterns of selected landraces in crossing with three commercial inbred testers.

\section{Materials and methods}

Plant material. Based on 27 morphological traits according to CIMMYT/IBPGR descriptors for maize (Zea mays L.) (IBPGR, 1991), 310 Western Balkan landraces were classified into eleven homogenous groups (Babić et al., 2015). For the purpose of selection of the best performing landraces from the pool of 310 landraces they were sown by groups in two replications at Zemun Polje $\left(44^{\circ} 51^{\prime} \mathrm{N}, 20^{\circ} 18^{\prime} \mathrm{E} ; 73 \mathrm{~m}\right.$ a.s.1.) during two-year (2013 and 2014) trial. Selection of the landraces was based upon characterisation for breeding important traits as follows: beginning and mid-flowering date (i.e. $10 \%$ and $50 \%$ of anthesis and silking), the plant and ear height, the intensity of a leaf green colour (on the 1-3 scale: 1 - light green, 2 - medium green and 3 - dark green), the number of lodged and broken plants, the number of ears, grain yield per plot as well as visual ear assessment ( 1 - poor, 2 - medium, 3 -good). A sample of 10 ears was used to determine the grain moisture content and grain type according to the International Union for the Protection of Cultivated Varieties of Plants (UPOV) descriptor (https://www.upov.int/edocs/tgdocs/en/tg002. pdf): 1 - flint, 2 - flint-like, 3 - intermediate, 4 - dentlike, 5 -dent, 6 - sweet, 7 - pop.

In parallel, five commercial inbred lines as potential testers were sown in 2013 and 2014: L225/755 ('Lancaster' germplasm), L73B013 (BSSS $\times$ 'Iowa Dent'), L217 ('Iowa Dent'), F2 (French public line) and Polj17 (line obtained by pedigree selection from the crossing of a two early Poland lines) in order to evaluate the date of flowering under the same environmental conditions as important data for subsequent crossings.

In the next season (2015), the best performing 40 Western Balkan landraces were crossed with three most successful testers under technical isolation. Crossing with tester was considered successful in the case when 15 ears with full seed set were obtained per landrace. The obtained ears were shelled in a way that equal seed quantity was taken from each ear in order to get total seed amount needed for yield trials. Out of 40 landraces, 31 were successfully crossed with selected inbred testers, thus 93 top-cross hybrids were obtained. Besides, inbred testers were mutually crossed (L73B013 $\times$ L217, L73B013 × L255/75-5 and L255/75-5 × L217), and three F1 hybrids were obtained and used as check hybrids in field trials.

Field experiment. For testing of performances regarding top cross hybrids obtained, a two-year field trial was conducted during 2017 and 2018 at four locations: Zemun Polje (445 $1^{\prime} \mathrm{N}, 20^{\circ} 18^{\prime} \mathrm{E} ; 73 \mathrm{~m}$ a.s.l.), Pančevo (44⒏ $88^{\prime} \mathrm{N}, 20^{\circ} 77^{\prime} \mathrm{E}$; $78 \mathrm{~m}$ a.s.1.), Sremska Mitrovica $\left(45^{\circ} 02^{\prime} \mathrm{N}, 1^{\circ} 64^{\prime} \mathrm{E} ; 88 \mathrm{~m}\right.$ a.s.l.) and Bečej $\left(45^{\circ} 69^{\prime} \mathrm{N}, 19^{\circ} 91^{\prime} \mathrm{E}\right.$; $80 \mathrm{~m}$ a.s.1.). According to European Environmental Stratification (Metzger et al., 2013), the experimental sites are assigned to Pannonian 3 (PAN3) zone within temperate continental climate. Trials were set up according to balanced incomplete block design with four blocks within each replication. Each genotype was sown in two $5 \mathrm{~m}$ long rows, with intra and inter row spacing of $0.20 \mathrm{~m}$ and $0.75 \mathrm{~m}$, respectively, i.e. plant density was 66700 plants ha ${ }^{-1}$. Standard cropping practices applied are presented in Table 1. After harvesting, grain yield was measured, calculated at $14 \%$ of water content and expressed in $\mathrm{t} \mathrm{ha}^{-1}$.

Statistical analysis. Analysis of variance (ANOVA) for data combined over 4 locations and 2 years (i.e. 8 environments) was done with statistical software MSTAT-C (Michigan State University, USA). Environments and environment by entry interactions were considered as random effects, while effects of inbred testers and landraces (mother) were considered as fixed effects. $F$-test was computed to determine the significance of different sources of variations and their partitioned effects within the combined ANOVA. Least significant difference (LSD) test was used to compare means of landraces (mother) and inbred testers (father) effects at $p \leq 0.05$. In this way, the landrace with the best general combining abilities (GCA) for the grain yield was identified. Expression of specific combining abilities (SCA) for grain yield was measured as $75 \%$ of grain yield of coupled F1 hybrids. Simple linear regression analysis was performed to identify the degree of association of the grain yield of landraces per se and their corresponding GCA values. 
Table 1. Crop management and weather data, and main soil characteristics for vegetative period (April to September)

\begin{tabular}{|c|c|c|c|c|c|c|c|c|}
\hline & \multicolumn{2}{|c|}{ Zemun Polje } & \multicolumn{2}{|c|}{ Pančevo } & \multicolumn{2}{|c|}{ Sremska Mitrovica } & \multicolumn{2}{|c|}{ Bečej } \\
\hline & 2017 & 2018 & 2017 & 2018 & 2017 & 2018 & 2017 & 2018 \\
\hline Sowing date & 1704 & 1404 & 604 & 404 & 1004 & 1204 & 1504 & 1604 \\
\hline Harvesting date & 1509 & 2409 & 1009 & 1809 & 2709 & 210 & 3009 & 710 \\
\hline Average temperature ${ }^{\circ} \mathrm{C}$ & 20.43 & 19.87 & 21.07 & 19.90 & 19.22 & 18.72 & 19.68 & 19.49 \\
\hline $\begin{array}{l}\text { Average amount } \\
\text { of precipitation } \mathrm{mm}\end{array}$ & 50.25 & 60.35 & 46.27 & 81.05 & 56.43 & 57.17 & 50.81 & 66.19 \\
\hline Soil type & \multicolumn{2}{|c|}{$\begin{array}{l}\text { slightly calcareous } \\
\text { chernozem }\end{array}$} & \multicolumn{2}{|c|}{ silty chernozem } & \multicolumn{4}{|c|}{ calcareous chernozem } \\
\hline $\begin{array}{l}\text { Humus-accumulative } \\
\text { horizon }\end{array}$ & \multicolumn{8}{|c|}{ profile Ah-AhC-C } \\
\hline $\begin{array}{l}\mathrm{pH} \text { in } \mathrm{H}_{2} \mathrm{O} \\
\mathrm{pH} \text { in } \mathrm{KCl} \\
\text { Total } \mathrm{N} \% \\
\mathrm{P}_{2} \mathrm{O}_{5} \mathrm{mg} 100 \mathrm{~g}^{-1} \\
\mathrm{~K}_{2} \mathrm{O} \mathrm{mg} 100 \mathrm{~g}^{-1} \\
\text { Organic matter \% }\end{array}$ & & & & & & & & \\
\hline Tillage & \multicolumn{8}{|c|}{ deep tillage (at $30 \mathrm{~cm}$ in the autumn) and pre-sowing soil preparation (in the spring) } \\
\hline \multirow{2}{*}{ Fertilization } & \multicolumn{8}{|c|}{$120 \mathrm{~kg} \mathrm{ha}^{-1}$ of NPK $(10: 52: 0)$ in the autumn } \\
\hline & \multicolumn{4}{|c|}{$300 \mathrm{~kg} \mathrm{ha}^{-1}$ of urea in the spring, before sowing } & \multicolumn{4}{|c|}{$280 \mathrm{~kg} \mathrm{ha}^{-1}$ of urea in the spring, before sowing } \\
\hline Weed control & \multicolumn{8}{|c|}{$\begin{array}{l}\text { pre-emergence application with Terbis and Mont (a.i. terbuthylazine and S-metolachlor); } \\
\text { post-emergence application with Innovate and Callisto (a.i. nicosulfuron and mesotrione) }\end{array}$} \\
\hline
\end{tabular}

\section{Results}

Selection of plant material. Based on the collected data, landraces were chosen for further evaluation, by applying main principle of favourable expression of as many as possible observed traits per $s e$. Landraces that were chosen showed grain yield per se significantly better in comparison with group mean, exhibiting low anthesis-silking interval, low positioned ear and dark green colour of leaf. Low number of lodged and broken plants as well as general ear appearance score was considered as important for landrace selection. Applying these complex criteria, 40 landraces were initially selected (10-15\% per homogenous group). Main characteristics of selected landraces are given in Table 2.

Table 2. Main passport data and evaluated parameters per se for maize landraces and commercial inbred testers used for combining ability testing

\begin{tabular}{|c|c|c|c|c|c|c|c|c|c|c|c|c|}
\hline $\begin{array}{l}\text { Homogenous } \\
\text { group }\end{array}$ & $\begin{array}{c}\text { Accession } \\
\text { No. }\end{array}$ & $\begin{array}{l}\text { Country of } \\
\text { collection }\end{array}$ & $\begin{array}{c}\mathrm{AL} \\
\mathrm{m} \\
\text { a.s.l. }\end{array}$ & $\begin{array}{l}\mathrm{PH} \\
\mathrm{cm}\end{array}$ & $\begin{array}{l}\mathrm{EH} \\
\mathrm{cm}\end{array}$ & $\begin{array}{c}\mathrm{EH}: \mathrm{PH} \\
\%\end{array}$ & LBP & $\begin{array}{c}\mathrm{Y} \\
\mathrm{t} \mathrm{ha}^{-1}\end{array}$ & GEA & $\mathrm{GC}$ & KT & ASI \\
\hline 1 & 2 & 3 & 4 & 5 & 6 & 7 & 8 & 9 & 10 & 11 & 12 & 13 \\
\hline \multirow[b]{2}{*}{1} & 1869 & HR & 850 & 147 & 30 & 20.47 & 5 & 3.46 & 2 & 3 & 1 & 0 \\
\hline & 1890 & $\mathrm{HR}$ & 600 & 147 & 41 & 27.68 & 4 & 4.27 & 3 & 2 & 1 & -2 \\
\hline \multirow{7}{*}{2} & 594 & MK & 661 & 175 & 62 & 35.62 & 1 & 3.04 & 2 & 2 & 1 & 3 \\
\hline & 773 & RS & 500 & 188 & 52 & 27.74 & 2 & 4.23 & 3 & 3 & 1 & 2 \\
\hline & 1185 & $\mathrm{ME}$ & 215 & 160 & 38 & 23.59 & 3 & 3.45 & 3 & 3 & 1 & -2 \\
\hline & 589 & MK & 661 & 168 & 56 & 33.02 & 2 & 2.39 & 3 & 1 & 1 & 1 \\
\hline & 1379 & BA & 650 & 169 & 44 & 26.42 & 6 & 2.12 & 2 & 1 & 1 & 1 \\
\hline & 1381 & BA & 700 & 190 & 53 & 28.33 & 5 & 4.50 & 3 & 2 & 2 & 0 \\
\hline & 1267 & $\mathrm{ME}$ & 500 & 202 & 54 & 27.07 & 0 & 4.53 & 2 & 2 & 3 & 1 \\
\hline \multirow{3}{*}{3} & 13 & $\mathrm{ME}$ & 900 & 174 & 54 & 31.23 & 3 & 3.14 & 3 & 3 & 1 & 0 \\
\hline & 467 & $\mathrm{BA}$ & 500 & 159 & 34 & 21.19 & 2 & 3.68 & 3 & 3 & 1 & 0 \\
\hline & 144 & RS & 900 & 181 & 67 & 36.81 & 1 & 4.39 & 3 & 2 & 1 & 4 \\
\hline \multirow{7}{*}{4} & 871 & MK & 105 & 164 & 43 & 26.30 & 3 & 3.55 & 3 & 3 & 2 & 3 \\
\hline & 1960 & $\mathrm{BA}$ & 750 & 178 & 46 & 25.83 & 4 & 4.84 & 2 & 3 & 3 & 0 \\
\hline & 1276 & $\mathrm{ME}$ & 800 & 195 & 57 & 29.28 & 3 & 4.97 & 2 & 3 & 4 & -1 \\
\hline & 846 & $\mathrm{BA}$ & 700 & 182 & 48 & 26.32 & 10 & 3.35 & 3 & 3 & 3 & 2 \\
\hline & 1384 & BA & 650 & 185 & 50 & 27.07 & 7 & 3.99 & 3 & 3 & 3 & 2 \\
\hline & 2144 & HR & 620 & 175 & 45 & 25.77 & 3 & 3.41 & 3 & 2 & 1 & -2 \\
\hline & 1534 & $\mathrm{RS}$ & 174 & 197 & 68 & 34.51 & 1 & 5.44 & 3 & 3 & 1 & 6 \\
\hline \multirow{2}{*}{5} & 642 & $\mathrm{RS}$ & 533 & 184 & 45 & 24.77 & 4 & 4.29 & 2 & 3 & 1 & 1 \\
\hline & 1798 & $\mathrm{RS}$ & 550 & 195 & 70 & 35.76 & 0 & 5.36 & 3 & 2 & 3 & 1 \\
\hline \multirow{3}{*}{6} & 1895 & HR & 500 & 181 & 56 & 30.53 & 3 & 5.14 & 3 & 2 & 1 & 1 \\
\hline & 2033 & HR & 50 & 198 & 71 & 35.80 & 2 & 5.47 & 3 & 3 & 3 & 1 \\
\hline & 2006 & BA & 800 & 206 & 81 & 39.37 & 3 & 5.48 & 3 & 2 & 1 & 0 \\
\hline \multirow{3}{*}{7} & 2230 & BA & 700 & 189 & 53 & 28.14 & 2 & 4.84 & 3 & 3 & 2 & 1 \\
\hline & 2236 & BA & 750 & 205 & 59 & 28.87 & 2 & 4.20 & 3 & 3 & 2 & 1 \\
\hline & 2176 & SI & 620 & 210 & 55 & 26.28 & 4 & 4.19 & 3 & 1 & 1 & 4 \\
\hline \multirow{4}{*}{8} & 2249 & $\mathrm{BA}$ & 800 & 230 & 90 & 39.08 & 2 & 7.74 & 3 & 2 & 5 & 2 \\
\hline & 2036 & BA & 800 & 205 & 72 & 34.54 & 3 & 5.98 & 3 & 2 & 4 & -2 \\
\hline & 1665 & MK & 700 & 218 & 91 & 41.90 & 0 & 5.79 & 3 & 2 & 4 & 2 \\
\hline & 632 & RS & 400 & 220 & 94 & 43.19 & 4 & 5.34 & 2 & 2 & 5 & 1 \\
\hline \multirow{2}{*}{9} & 1945 & BA & 700 & 204 & 72 & 35.02 & 5 & 4.45 & 3 & 3 & 1 & 1 \\
\hline & 2047 & HR & 180 & 209 & 88 & 42.27 & 3 & 4.69 & 2 & 1 & 4 & 6 \\
\hline
\end{tabular}


Table 2 continued

\begin{tabular}{cccccccccccccc}
\hline 1 & 2 & 3 & 4 & 5 & 6 & 7 & 8 & 9 & 10 & 11 & 12 & 13 \\
\hline \multirow{2}{*}{10} & 1346 & ME & 200 & 225 & 80 & 35.60 & 6 & 5.88 & 3 & 3 & 5 & 2 \\
& 877 & BA & 41 & 206 & 68 & 33.18 & 1 & 5.36 & 3 & 3 & 3 & 5 \\
& 1569 & SI & 103 & 261 & 121 & 46.23 & 3 & 5.92 & 3 & 3 & 5 & 4 \\
\hline \multirow{4}{*}{11} & 197 & SI & 200 & 213 & 77 & 36.03 & 1 & 4.65 & 3 & 3 & 5 & 3 \\
& 288 & RS & 80 & 221 & 85 & 38.32 & 3 & 5.23 & 3 & 1 & 5 & 5 \\
& 1509 & SI & 200 & 216 & 87 & 40.07 & 5 & 6.92 & 3 & 3 & 5 & 1 \\
& 1450 & HR & 300 & 233 & 98 & 41.69 & 8 & 5.73 & 3 & 3 & 5 & 2 \\
\hline & L217 & Iowa Dent (ID) & 182 & 57 & 31.32 & 0 & 3.20 & 3 & 3 & 5 & 1 \\
& L73B013 & BSSS $\times$ ID & 174 & 60 & 34.48 & 0 & 3.85 & 3 & 3 & 4 & 0 \\
& L255/75-5 & Lancaster & 178 & 58 & 32.58 & 1 & 2.96 & 3 & 2 & 4 & 1 \\
\hline
\end{tabular}

$\mathrm{AL}$ - altitude of collection site (meters above sea level), $\mathrm{PH}$ - plant height, EH - ear height, $\mathrm{PH}: \mathrm{EH}$ - plant and ear height ratio, LBP - lodged and broken plants, Y - yield, GEA - general ear assessment, GC - leaf green colour, KT - kernel type, ASI anthesis silking interval; HR - Croatia, MK - Republic of Northern Macedonia, RS - Serbia, ME - Montenegro, BA - Bosnia and Herzegovina, SI - Slovenia

Because of poor agronomic traits, poor tassel development, low pollen productivity and pollen abortiveness, inbred testers F2 and Polj17 were excluded. Further crossing was done with remaining three inbred testers L217, L255/75-5 and L73B013.

Multi-environment trials. Out of eight environments, seven were used for statistical processing, since location Zemun Polje in 2017 was eliminated due to poor plant stands as a consequence of serious trial damage in early stages of plant development caused by birds. Analysis of variance showed that effects of landrace and effect of tester were highly significant $(p \leq 0.01)$ as well as their interaction $(p \leq 0.05, p \leq 0.01)$ (Table 3$)$.

Table 3. Analysis of variance for maize grain yield

\begin{tabular}{ccccc}
\hline Source of variation & DF & SS & MS & $F$ value \\
\hline Location (L) & 6 & 4002.82 & 667.14 & $429.23^{* *}$ \\
Replication / L & 7 & 22.14 & 3.16 & $2.04^{*}$ \\
Block / replications & 6 & 14.02 & 2.34 & $1.50 \mathrm{~ns}$ \\
Inbred tester (A) & 2 & 157.78 & 78.8988 & $50.76^{* *}$ \\
L $\times$ A & 12 & 127.72 & 10.64 & $6.85^{* *}$ \\
Landrace (B) & 30 & 244.11 & 8.14 & $5.24^{* *}$ \\
L $\times$ B & 180 & 246.28 & 1.37 & $0.88 \mathrm{~ns}$ \\
A $\times$ B & 60 & 192.47 & 3.21 & $2.06^{* *}$ \\
L $\times$ A $\times$ B & 360 & 657.38 & 1.83 & $1.18^{*}$ \\
Error & 644 & 1000.94 & 1.55 & \\
\hline Total & 1301 & 6665.62 & & \\
\hline DF
\end{tabular}

DF - degree of freedom, SS - sum of squares, MS - mean square; *** - significant at 0.05 and 0.01 probability level, respectively; ns - non significant
Table 4 presents landrace effects in crosses with all inbred testers. It can be seen that the highest average grain yield was obtained in crosses with landrace 1267 $\left(8.36 \mathrm{t} \mathrm{ha}^{-1}\right)$. Grain yield of crosses with landraces 1346, 197, 1569, 1509 and 2036 does not differ significantly. It can be concluded that these landraces showed the best GCA for grain yield. Landrace 1267 belongs to the second group of early landraces. This semi-flint kernel type landrace is also characterized by high grain yield per se as well as by strong high stalk (Table 2). The rest of the landraces that showed good GCA were dent kernel type landraces and belonged to $8^{\text {th }}(2036), 10^{\text {th }}$ $(1346,1569)$ and $11^{\text {th }}(197,1509)$ homogenous group, respectively, where dent kernel type landraces prevailed. The correlation between landrace grain yield per se and average yield of landrace crosses with all testers was significant $(r=0.351, p \leq 0.05)$.

Looking at inbred tester effects, it is obvious that landraces gave the best results in crosses with L73B013 $(87.5 \%$ BSSS $\times 12.5 \%$ 'Iowa Dent'), classified as Iowa Stiff Stalk Synthetic heterotic group (Table 5). Also, it can be seen that grain yield in crosses with L217 ('Iowa Dent') does not differ significantly. This was expected to a certain extent, since inbred testers L217 and L73B013 share the common germplasm (i.e. $12.5 \%$ 'Iowa Dent'). However, significantly lower $(p \leq 0.05)$ grain yield was obtained in crosses with L255/75-5 ('Lancaster').

Besides information on GCA, it is important to know SCA, i.e. how particular population performs in crosses with each inbred tester separately. In the

Table 4. Effect of landrace (mother) on maize grain yield in top-crosses with three inbred testers

\begin{tabular}{|c|c|c|c|c|c|c|c|c|}
\hline $\begin{array}{c}\text { Ranked } \\
\text { order }\end{array}$ & $\begin{array}{c}\text { Accession } \\
\text { No. }\end{array}$ & $\begin{array}{c}\text { AYTCHL } \\
\mathrm{t} \mathrm{ha}^{-1}\end{array}$ & $\begin{array}{c}\text { Ranked } \\
\text { order }\end{array}$ & $\begin{array}{c}\text { Accession } \\
\text { No. }\end{array}$ & $\begin{array}{c}\text { AYTCHL } \\
\mathrm{t} \mathrm{ha}^{-1}\end{array}$ & $\begin{array}{c}\text { Ranked } \\
\text { order }\end{array}$ & $\begin{array}{c}\text { Accession } \\
\text { No. }\end{array}$ & $\begin{array}{c}\text { AYTCHL } \\
\mathrm{t} \mathrm{ha}^{-1}\end{array}$ \\
\hline 1 & 1267 & $8.36 \mathrm{a}$ & 12 & 1895 & 7.63 cdefg & 23 & 1534 & 7.25 fghijk \\
\hline 2 & 1346 & $8.26 \mathrm{ab}$ & 13 & 773 & 7.61 defgh & 24 & 1450 & 7.22 ghijkl \\
\hline 3 & 197 & $8.1 \mathrm{abc}$ & 14 & 1798 & 7.59 defgh & 25 & 2144 & 7.18 ghijkl \\
\hline 4 & 1569 & $7.9 \mathrm{abcd}$ & 15 & 594 & 7.50 defghi & 26 & 846 & 7.14 hijkl \\
\hline 5 & 1509 & 7.92 abcde & 16 & 642 & 7.46 defghii & 27 & 13 & $6.99 \mathrm{ijkl}$ \\
\hline 6 & 2036 & 7.87 abcde & 17 & 1945 & 7.42 defghijk & 28 & 1960 & $6.93 \mathrm{jklm}$ \\
\hline 7 & 1665 & 7.76 bcdef & 18 & 288 & 7.41 efghijk & 29 & 2006 & $6.90 \mathrm{klm}$ \\
\hline 8 & 871 & 7.75 bcdef & 19 & 2047 & 7.33 fghijk & 30 & 467 & $6.74 \mathrm{~lm}$ \\
\hline 9 & 1276 & 7.75 bcdef & 20 & 1348 & 7.32 fghijk & 31 & 1890 & $6.42 \mathrm{~m}$ \\
\hline 10 & 877 & 7.71 cdefg & 21 & 632 & 7.29 fghijk & & & \\
\hline 11 & 2249 & 7.71 cdefg & 22 & 2033 & 7.26 fghijkl & & & \\
\hline
\end{tabular}

AYTCHL - average grain yield of top-cross hybrids of particular landrace; LSD value $=0.534$ at 0.050 probability level

Table 5. Effect of inbred tester (father) on maize grain yield in top-crosses

\begin{tabular}{ccc}
\hline Ranked order & Tester & AYTCHT t ha $^{-1}$ \\
\hline 1 & L73B013 & $7.75 \mathrm{a}$ \\
2 & L2 17 & $7.69 \mathrm{a}$ \\
3 & L255/75-5 & $6.99 \mathrm{~b}$ \\
\hline
\end{tabular}

AYTCHT - average grain yield of top-cross hybrids of particular tester; LSD value $=0.1662$ at 0.050 probability level population, change in vigour is directly proportional to the change in heterozygosity being highly correlated with yield. The probability for an allele to give a heterozygote in crossing of a population, which is at equilibrium $(p=q=0.5)$ for the locus (i.e. $25 \%$ AA:50\% Aa:25\% aa) to inbred with fixed locus (i.e. $100 \%$ AA or $100 \%$ aa) is $75 \%$ (Hallauer et al., 2010). Therefore, $75 \%$ of single cross hybrid yield is taken as a referent value. Given that 
the yield is a complex trait and that not all the alleles that determine population yield are in equilibrium, topcross hybrids could exhibit lower / higher yield value compared to the referent one. Namely, top-cross hybrids obtained by crossing of landraces (i.e. 1960, 642, 2006, $1945,1346,1665,1509,1534,1450$ and 1569$)$ to L217 tester, reached yield $\left(7.61 \mathrm{t} \mathrm{ha}^{-1}\right)$ above referent line (Fig. 1). The highest yield $\left(8.80 \mathrm{t} \mathrm{ha}^{-1}\right)$ was achieved by the combination $1945 \times$ L217, which represents $87 \%$ of yield obtained by corresponding F1 hybrid (i.e. $10.11 \mathrm{t} \mathrm{ha}^{-1}$ ). Landraces 1960, 773, 1798, 1665, 632, 877 and 1569 exhibited heterosis for grain yield in crossings with tester L73B013. The referent value (i.e. $75 \%$ of the F1 hybrids of the given tester) was $7.98 \mathrm{t} \mathrm{ha}^{-1}$. The highest average yield $\left(8.86 \mathrm{t} \mathrm{ha}^{-1}\right)$ in crossings with this tester was achieved by the landrace 877 (Fig. 2).

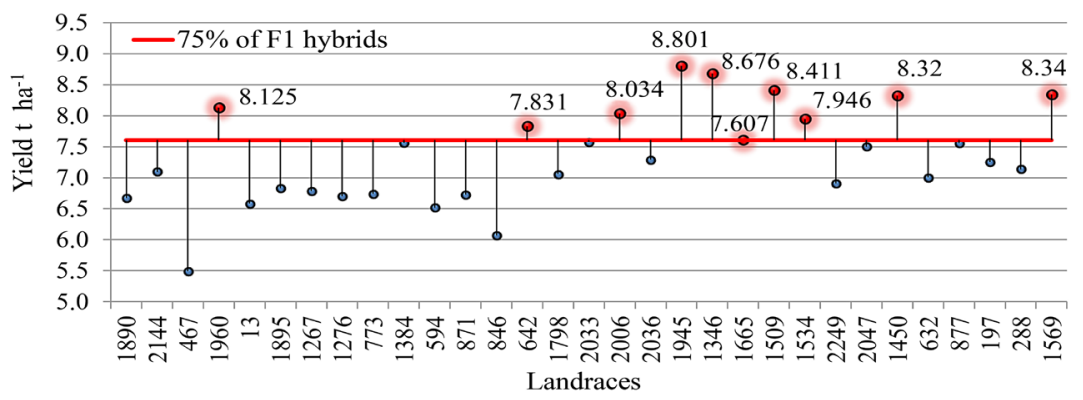

Figure 1. Specific combining abilities (SCA) of grain yield for evaluated maize landraces in crosses with inbred tester L217 based on two-year testing over four locations

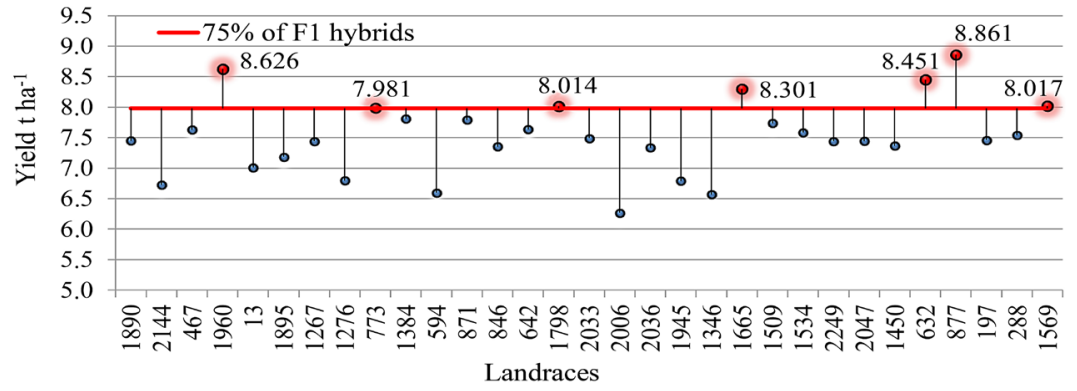

Figure 2. Specific combining abilities (SCA) of grain yield for evaluated maize landraces in crosses with inbred tester L73B013 based on two-year testing over four locations

Seventy-five percent of the average yield of F1 hybrids for tester L255/75-5 was $8.15 \mathrm{tha}^{-1}$. Therefore, it can be concluded that the landraces 467, 773, 1346, 1534, 2249 and 288 exhibited heterosis in crossings with tester L255/75-5. The landrace 288 gave the highest average yield (9.25 $\mathrm{t} \mathrm{ha}^{-1}$ ) in crossings with this tester (Fig. 3).
It was noticed that a certain number of landraces expressed heterotic effect with two inbred testers, while none expressed heterotic effect with all three inbred testers. To a certain extent it was expected, as inbred testers were chosen in a way that they represent all major heterotic groups used in commercial maize breeding

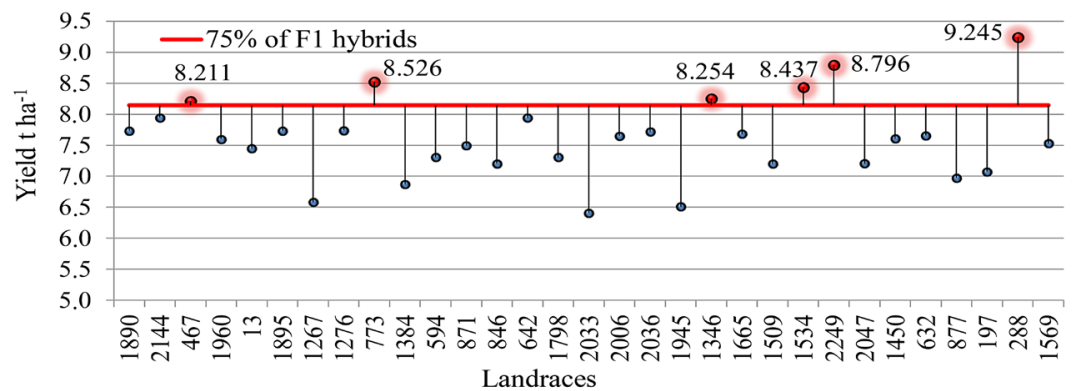

Figure 3. Specific combining abilities (SCA) of grain yield for evaluated maize landraces in crosses with inbred tester L255/75-5 based on two-year testing over four locations

programs. Thus, landraces 1960,1665 and 1569 combined well with L217 and L73B013. Landraces 1534 and 1346 expressed heterotic effect in crosses with L217 and L255/75-5, while heterotic effect in crosses with L73B013 and 255/75-5 was achieved by landrace 773 (Fig. 4).

Landraces 1346, 1569 and 1509, besides showing high GCA values, also expressed high SCA in crosses with particular inbred testers. Landrace 1346 expressed heterotic effect in cross with L217 and L255/75-5, landrace 1569 with L217 and L73B013, while landrace 1509 combined well with L217. Particularly interesting is landrace 1346, which besides high GCA, combined well with two inbred testers being parental components of one commercial F1 hybrid. In addition, special attention should be paid to semi-flint landrace 773 having heterotic effect in crosses with divergent testers that represent parental components of commercial F1 hybrid. 


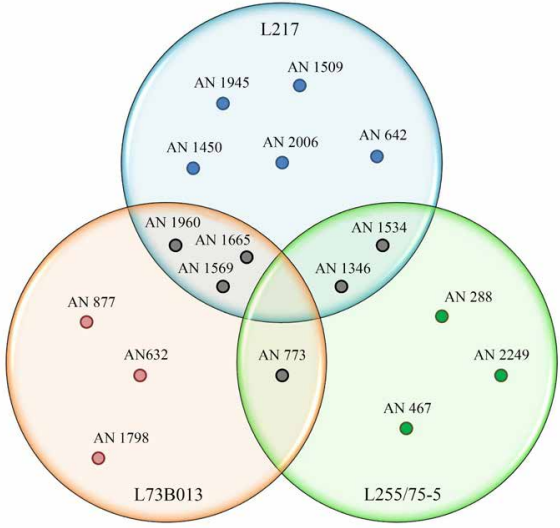

Figure 4. Heterotic effect of the maize landraces in crossing with inbred testers used

\section{Discussion}

A huge number of samples stored in gene banks frequently represent aggravating factor for more efficient use of available genetic variability. Classification of Western Balkan landraces into distinct homogenous groups was performed in order to select a smaller number of accessions for further work, retaining as much genetic variability of the initial genetic pool as possible (Babic et al., 2015). A detailed classification of accessions into similar and related groups should be performed before the selection of a core subset, because significant amounts of crop diversity are often distributed both between and within such groups, especially in out-crossing species like maize is (Mayer et al., 2017). However, characterization of landraces according to CIMMYT/IBPGR descriptors for maize (IBPGR, 1991), that was used for classification, does not contained important information from breeding standpoint, such are grain yield, stalk traits and heterotic pattern. Basic knowledge on the genetic potential of base populations, either per se or in crosses, is important information in breeding programs for the development of outstanding cultivars (Böhm et al., 2017). In this study, final selection of the landraces, in order to evaluate their combining abilities and heterotic pattern, was performed proportionally (i.e. $10-15 \%$ from each group) and was based on expression of as many as possible favourable traits per se. It was assumed that most of the variability contained in initial pool of 310 Western Balkan landraces was captured in selected landraces.

Flowering synchrony between male and female parents of maize hybrids is an important driver for improved kernel set and grain yield (Worku et al., 2016). In order to evaluate the date of flowering under the same environmental conditions, five commercial testers were sown. Three best performing divergent inbred testers, belonging to FAO 300-400 maturity groups (medium early), were chosen for subsequent testing. Likewise, in spite of the fact that landraces were sown in technical isolation and in four planting dates during a period of 27 days $\left(23^{\text {rd }}\right.$ April, $3^{\text {rd }}, 11^{\text {th }}$ and $20^{\text {th }}$ May), not all crosses succeeded. For extra-early landraces, it could be a consequence of inadequate growth conditions, probably influenced by the length of day.

In hybrid breeding, information about the per se performance is only of secondary importance, because the parents are chosen in such a way that heterosis in hybrid combinations is maximized. Information about correlation between per se performance of lines produced from landraces and their testcross performance is lacking. Böhm et al. (2017) stated that this information is important for efficient utilization of the genetic diversity from landraces. Thus, it is very important to provide information about heterotic pattern before including gene banks' material into commercial breeding program. For this reason, many studies focused on heterotic grouping of landraces and identification of promising heterotic patterns among them (Revilla et al., 2006; Brauner et al., 2019). Vančetović et al. (2015 b) pointed out that the value of initial population for breeding, if F1 hybrid is the main goal, besides characteristics per se, depends on its combining abilities in crosses with another population, group of populations or inbred line.

In this study, results of multi environment trial show that effects of landraces, inbred testers as well as their interactions (except location by landrace interaction) were significant. This indicates that high intra variety divergences of top-cross hybrids for landraces resulted in similar response across environments (Table 2).

GCA results indicated that dent landraces 1346 , 197, 1569, 1509 and 2036 generally combined better for grain yield. Statistical significance of correlation of landrace grain yield per se and average performance of landrace in crosses with inbred testers indicated additive gene effect as the main for grain yield GCA. Melani and Carena (2005) also found a positive linear relationship between grain yield of the populations per se and their corresponding GCA values. Over time, the yield gap between the genetic resources and the elite breeding materials will increase due to the annual selection progress of $1-2 \%$ for grain yield in maize cultivars. To fill this gap, it is necessary to initiate new or continue existing programs in the pre-breeding domain to evaluate the breeding value of the landraces for more complex traits, especially yield. This could be accelerated by using modern tools like production of doubled haploid lines from landraces in spite of their outperformance in comparison with elite flint lines (Wilde et al., 2010). Gouesnard et al. (2016) reported that evaluated populations originating from dry South European cropping zones showed adaptive traits to drought and could be used in breeding despite existing yield gap between these populations and elite material.

Only a small numbers of flint landraces were evaluated for their combining ability with testers from different heterotic groups to analyse main effects and interactions of landraces and testers under this setting (Soengas et al., 2006). Thus, detection of semi-flint landrace 1267 with the best GCA is of particular importance. However, landraces cannot be used directly as parental components in hybrid breeding. Long-term improvement programs are of essential importance for their breeding potential utilization. On the other hand, the tester(s) from the opposite heterotic pool will probably change over time. Therefore, it is another reason why it is important to have information about landraces GCA. Hölker et al. (2019) recommend the use of broad testers from the opposite pool like single-cross or even doublecross testers, as this will reduce SCA effects according to quantitative genetic theory.

In this study, the highest yield was observed in crossing to L73B013, consisting of $87.5 \%$ BSSS germplasm. The effect of the 'Iowa Dent' tester L217 did not statistically differ. The obtained significantly lower average yield of the top-cross hybrids in crosses to the tester line L255/75-5 of 'Lancaster' origin pointed out to a greater relatedness of local germplasm with this heterotic pool (Table 4). This result is in accordance with the fact that inbreds derived from the Western Balkan landraces within the national maize breeding programmes in former Yugoslavia crossed well to public USA inbreds, developed from the USA Corn Belt synthetics (Babić 
et al., 2011). Similar heterotic patterns were recorded between the European commercial flints and the USA dents (Reif et al., 2005; Soengas et al., 2006).

Most temperate maize hybrid breeding programs utilize Stiff Stalk and non-Stiff Stalk heterotic pattern within the 'Corn Belt Dent' race, which has already undergone many cycles of selection, primarily for grain yield (Bertoia et al., 2006). Böhm et al. (2015) recommended assessing the breeding potential of landraces for broadening existing heterotic groups by evaluating their testcross performance in combination with one or two elite single-cross tester(s) from the opposite heterotic pool.

The largest number of evaluated (ten) landraces expressed heterosis with tester line L217, followed by seven with tester L73B013, and six with tester L255/75-5 of 'Lancaster' origin (Figs 1-3). In addition, some landraces gave good results simultaneously with two testers (Fig. 4). Good simultaneous performing of landraces 1960, 1665 and 1569 with testers L217 ('Iowa Dent') and L76B013 can partially be explained by a small portion of 'Iowa Dent' germplasm contained in L73B013 $(12.5 \%)$. On the other hand, landraces 1534, 1346 and 773 performed well with two divergent inbred testers that are components of commercially successful hybrids. Accordingly, it can be assumed that landraces showing heterotic effect simultaneously in crosses with L255/755 and L217 as well as landraces having heterotic effect simultaneously in crosses with L255/75-5 and L72B013 represent an independent heterotic group.

Results of our experiment are in line with previously reported results, which indicated good performance of inbred lines derived from local germplasm in crosses with inbred lines derived from 'Lancaster Sure Crop' and 'Reid Yellow Dent' open pollinated cultivars and lines derived from 'Pioneer' hybrids (Li et al., 2002; 2004). Because of the narrow genetic base of commercial maize gene pool, utilization of local germplasm for searching of alternative heterotic patterns becomes interesting (Vančetović et al., 2015 b) and could especially be referred to flint landrace 773 .

European flint landraces are natural candidates for introgression into the flint heterotic pool, because this traces back to lines extracted from a small number of European flint landraces at the beginning of hybrid breeding (Reif et al., 2005; Wilde et al., 2010; Gouesnard et al., 2017; Brauner et al., 2019). For this reason, information about combining ability of the flint landraces in testcrosses with two representative elite tester lines from the dent heterotic pool is important.

\section{Conclusions}

1. In crossing with all three inbred testers, the effect of maize landrace 1267 was the highest $(8.36$ $\mathrm{t} \mathrm{ha}^{-1}$ ), followed by the effects of landraces 1346, 197 , 1569,1509 and 2036, pointing out to their best general combining abilities (GCA) for grain yield. Since the GCA is mainly under control of additive genes effects, these populations can be considered as the valuable donors of genes responsible for high grain yield in crossings with germplasm belonging to different heterotic groups.

2. Ten maize landraces expressed good specific combining abilities (SCA) with tester L217 ('Iowa Dent' heterotic group), seven with tester L73B013 (BSSS $\times$ 'Iowa Dent') and six with tester L225/75-5 ('Lancaster' germplasm).

3. The identified simultaneous heterotic effect with two divergent inbred testers implied the existence of an independent heterotic pool within the gene pool of local maize landraces evaluated.

\section{Acknowledgments}

This study was supported by the project "Exploitation of maize diversity to improve grain quality and drought tolerance" (TR 31028) of the Ministry of Education, Science and Technological Development, Republic of Serbia.

Received 05062019 Accepted 29012020

\section{References}

1. Andjelkovic V., Ignjatovic-Micic D. 2012. Maize genetic resources - science and benefits. Serbian Genetic Society, Belgrade. https://www.researchgate. net/publication/304056743 Maize Genetic ResourcesScience and Benefits-

2. Babić M., Anđelković V., Mladenović Drinić S., Konstantinov K. 2011. The conventional and contemporary technologies in maize (Zea mays L.) breeding at Maize Research Institut Zemun Polje. Maydica, 56 (2): 49-57. https://journals-crea.4science.it/index.php/maydica/article/ view/687/623

3. Babić V., Vančetović J., Prodanović S., Kravić N. Babić M., Anđelković V. 2015. Numerical classification of Western Balkan maize drought tolerant landraces. Journal of Agricultural Science and Technology, 17 (2): 455-468. http://jast.modares.ac.ir/ article 12232 8711c875192edd074d9cf7792c6a0ce2.pdf

4. Bertoia L., Lopez C., Burak R. 2006. Biplot analysis of forage combining ability in maize landraces. Crop Science, 46 (3): 1346-1353. https://doi.org/10.2135/cropsci2005.09-0336

5. Böhm J., Schipprack W., Mirdita V., Utz H. F., Melchinger A. E. 2015. Breeding potential of European flint maize landraces evaluated by testcross performance. Crop Science, 54 (4): 1665-1672. https://doi.org/10.2135/cropsci2013.12.0837

6. Böhm J., Schipprack W., Utz H. F., Melchinger A. E. 2017. Tapping the genetic diversity of landraces in allogamous crops with doubled haploid lines: a case study from European flint maize. Theoretical and Applied Genetics, 130 (5): 861-873.

https://doi.org/10.1007/s00122-017-2856-x

7. Brauner P. C., Schipprack W., Utz H. F., Bauer E., Mayer M., Schön C. C. Melchinger A. E. 2019. Testcross performance of doubled haploid lines from European flint maize landraces is promising for broadening the genetic base of elite germplasm. Theoretical and Applied Genetics, 132 (6): 1897-1908 https://doi.org/10.1007/s00122-019-03325-0

8. Curry H. A. 2017. Breeding uniformity and banking diversity: the genescapes of industrial agriculture, 19351970. Global Environment, 10 (1): 83-113. https://doi.org/10.3197/ge.2017.100104

9. Gorjanc G., Jenko J., Hearne S. J., Hickey J. M. 2016. Initiating maize pre-breeding programs using genomic selection to harness polygenic variation from landrace populations. BMC Genomics, 17: 30 . https://doi.org/10.1186/s12864-015-2345-Z

10. Gouesnard B., Zanetto A., Welcker C. 2016. Identification of adaptation traits to drought in collections of maize landraces from southern Europe and temperate regions. Euphytica, 209: 565-584. https://doi.org/10.1007/s10681-015-1624-8

11. Gouesnard B., Negro S., Laffray A., Glaubitz J., Melchinger A., Revilla P., Moreno Gonzalez J., Madur D., Combes V., Tollon Cordet C., Laborde J., Kermarrec D., Bauland C., Moreau L., Charcosset A., Nicolas S. 2017. Genotyping-by-sequencing highlights original diversity patterns within a European collection of 1191 maize flint lines, as compared to the maize USDA genebank Theoretical and Applied Genetics, 130 (10): 2165-2189. https://doi.org/10.1007/s00122-017-2949-6

12. Hallauer A. R., Carena M. J., Miranda Filho J. B. 2010. Quantitative genetics in maize breeding. ( $3^{\text {rd }}$ ed.). Springer, 664 p. https://doi.org/10.1007/978-1-4419-0766-0

13. Hölker A., Schipprack W., Molenaar W., Melchinger A. E. 2019. Progress for testcross performance within the flint heterotic pool of a public maize breeding program since the onset of hybrid breeding. Euphytica, 215 (3): 50. https://doi.org/10.1007/s10681-019-2370-0 
14. IBPGR. 1991. Descriptors for maize. International Maize and Wheat Improvement Center, Mexico City / International Board for Plant genetic Resources.

15. Le Clerc V., Bazante F., Baril C., Guiard J., Zhang D. 2005. Assessing temporal changes in genetic diversity of maize varieties using microsatellite markers. Theoretical and Applied Genetics, 110 (2): 294-302. https://doi.org/10.1007/s00122-004-1834-2

16. Li Y., Du J., Wang T., Shi Y., Song Y., Jia J. 2002. Genetic diversity and relationships among Chinese maize inbred lines revealed by SSR markers. Maydica, 47 (2): 93-101.

17. Li Y., Shi Y., Song Y., Du J., Tuberosa R., Wang T. 2004. Analysis of genetic diversity in maize inbred lines based on AFLP markers. Maydica, 49 (2): 89-95.

18. Mayer M., Unterseer S., Bauer E., de Leon N., Ordas B. Schön C. C. 2017. Is there an optimum level of diversity in utilization of genetic resources? Theoretical and Applied Genetics, 130 (11): 2283-2295.

https://doi.org/10.1007/s00122-017-2959-4

19. Melani M. D., Carena M. J. 2005. Alternative maize heterotic patterns for the Northern Corn Belt. Crop Science, 45 (6): $2186-2194$

https://doi.org/10.2135/cropsci2004.0289

20. Metzger M. J., Brus D. J., Bunce R. G. H., Carey P. D., Gonçalves J., Honrado J. P., Jongman R. H. G., Trabucco A., Zomer R. 2013. Environmental stratifications as the basis for national, European and global ecological monitoring. Ecological Indicators, 33: 26-35. https://doi.org/10.1016/j.ecolind.2012.11.009

21. Mikić S., Kondić-Špika A., Brbaklić Lj., Stanisavljević D. Ceran M., Trkulja D., Mitrović B. 2017. Molecular and phenotypic characterisation of diverse temperate maize inbred lines in Southeast Europe. Zemdirbyste-Agriculture, 104 (1): 31-40. https://doi.org/10.13080/z-a.2017.104.005

22. Nass L. L., Paterniani E. 2000. Pre-breeding: a link between genetic resources and maize breeding. Sciencia Agricola, 57 (3): 581-587. https://doi.org/10.1590/S0103-90162000000300035

23. Ortiz R., Taba S., Tovar V. H. C., Mezzalama M., Xu Y., Yan J., Crouch J. H. 2010. Conserving and enhancing maize genetic resources as global public goods - a perspective from CIMMYT. Crop Science, 50 (1): 13-28. https://doi.org/10.2135/cropsci2009.06.0297
24. Reif J. C., Hamrit S., Hechenberger M., Schipprack W., Maurer H. P., Bohn M., Melchinger A. E. 2005. Trends in genetic diversity among European maize cultivars and their parental components during the past 50 years. Theoretical and Applied Genetics, 111 (5): 838-845. https://doi.org/10.1007/s00122-005-0004-5

25. Revilla P., Boyat A., Alvarez A., Gouesnard B., Soengas P., Ordas A., Malvar R. A. 2006. Heterotic patterns among French and Spanish maize populations. Maydica, 51 (3): 525-535.

26. Shimelis H., Laing M. 2012. Timelines in conventional crop improvement: pre-breeding and breeding procedures. Australian Journal of Crop Science, 6 (11): 1542-1549. http://www.cropj.com/shimelis_6_11_2012_1542_1549.pdf

27. Soengas P., Ordás B., Malvar R. A., Revilla P., Ordás A. 2006. Combining abilities and heterosis for adaptation in flint maize populations. Crop Science, 46 (6): 2666-2669. https://doi.org/10.2135/cropsci2006.04.0230

28. Technow F., Schrag T. A., Schipprack W., Melchinger A. E. 2014. Identification of key ancestors of modern germplasm in a breeding program of maize. Theoretical and Applied Genetics, 127 (12): 2545-2553.

https://doi.org/10.1007/s00122-014-2396-6

29. Vančetović J., Ignjatović-Micić D., Božinović S., Delić N. 2015 (a). Maize core collection for increased grain quality. Maydica, 60 (4): 1-10. https://journals-crea.4science.it/ index.php/maydica/article/view/1280/968

30. Vančetović J., Božinović S., Ignjatović-Micić D., Delić N., Kravić N., Nikolić A. 2015 (b). A diallel cross among drought tolerant maize populations. Euphytica, 205 (1): 1-16. https://doi.org/10.1007/s10681-015-1372-9

31. Wilde K., Burger H., Prigge V., Presterl T., Schmidt W., Ouzunova M., Geiger H. H. 2010. Testcross performance of doubled-haploid lines developed from European flint maize landraces. Plant Breeding, 129 (2): 181-185. https://doi.org/10.1111/j.1439-0523.2009.01677.x

32. Worku M., Makumbi D., Beyene Y., Das B., Mugo S., Pixley K., Bänziger M., Owino F., Olsen M., Asea G., Prasanna B. M. 2016. Grain yield performance and flowering synchrony of CIMMYT's tropical maize (Zea mays L.) parental inbred lines and single crosses. Euphytica, 211 (3): 395-409.

https://doi.org/10.1007/s10681-016-1758-3

ISSN 1392-3196 / e-ISSN 2335-8947

Zemdirbyste-Agriculture, vol. 107, No. 2 (2020), p. 153-160

DOI 10.13080/z-a.2020.107.020

\title{
Paprastojo kukurūzo vietinių veislių selekcinio potencialo ivertinimas pagal bandomojo kryžminimo rezultatus
}

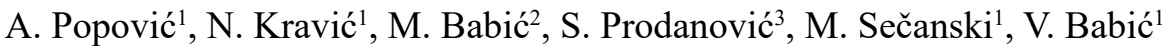 \\ ${ }^{1}$ Kukurūzų tyrimų institutas "Zemun Polje", Serbija \\ ${ }^{2}$ Lauko augalų ir daržovių institutas, Serbija \\ ${ }^{3}$ Belgrado universiteto Žemès ūkio fakultetas, Serbija
}

\section{Santrauka}

Didelès dalies augalų, ypač kryžmadulkių, pavyzdžiui, paprastojo kukurūzo (Zea mays L.), giminingu genotipu grupèse ir tų grupių viduje pastebima didelè ịvairovè. Siekiant praplèsti genetinę bazę, prieš panaudojant selekcinę medžiagą veislių kūrimo programoms, būtina atlikti išsamų Genu banko genotipų ivvertinimą ir klasifikaciją. Tyrimui buvo pasirinkta 40 vietinių veislių iš didelio Vakarų Balkanų fondo, kurios buvo sugrupuotos ị 11 homogeniškų grupių. Tyrimo tikslas - ịvertinti heterozini vietinių veislių efektyvumą, jas kryžminant su trimis skirtingais elitiniais testeriais L217, L73B013 ir L255/75-5. Pagal dvejų metų tyrimų, atliktų keturiose vietovėse, rezultatus, vietinès veislès 1267, 1346, 197, 1569, 1509 ir 2036 parodè geriausia bendra kombinacine geba jas vertinant pagal grūdų derlių. Vietinès veislès 1960, 642, 2006, 1945, 1346, 1569, 1450, 1534, 1509 ir 1665 pademonstravo gerus rezultatus kryžminant su testeriu L217, o vietinès veislès 1960, 773, 1798, 1665, 632, 877 ir 1569 parodè geriausius rezultatus jas kryžminant su inbrediniu testeriu L73B013. Kryžminant su inbrediniu testeriu L255/75-5 pasireiškė didžiausias heterozinis vietinių veislių 467, 773, 1346, 1534, 2249 ir 288 efektyvumas.

Didžiausią dėmesį reikètų skirti vietinių populiacijų veislėms 1346, 1569 ir 1509, pasižyminčioms ir didele bendra, ir specifine kombinacine geba. Kai kurios vietinès veislès parodè heterozę su dviem testeriais, o tai rodo naują, nesusijusį, negiminingą tirtos vietinès genetinès medžiagos vidinį heterozinị modelį.

Reikšminiai žodžiai: bendroji kombinacinè geba, derlius, genetiniai ištekliai, heterozinis modelis, specifinė kombinacinè geba, Zea mays. 